\title{
Heterogeneous Preferences and Investments in Energy Saving Measures
}

\author{
Urs Fischbacher ${ }^{\dagger} \quad$ Simeon Schudy ${ }^{\ddagger} \quad$ Sabrina Teyssier\$
}

June 5, 2015

\begin{abstract}
We investigate whether risk, time, environmental, and social preferences affect single family homeowners' investments in energy efficient renovations and energy quality of their house using established experimental measures and questionnaires. We find that homeowners who report to be more risk taking are more likely to have renovated their house. Pro-environmental and futureoriented renovators, i.e. renovators with lower discount factors, live in homes with higher energy efficiency. Controlling for the energy efficiency of houses, we further find that energy consumption as measured by heating and energy costs are lower for future-oriented and proenvironmental individuals. Social preferences measured in a dictator and a generosity game play a mixed role for investments in energy efficiency and energy consumption.
\end{abstract}

Keywords: Risk Preferences, Time Preferences, Environmental Preferences, Social Preferences, Energy Efficiency, Artefactual Field Experiment

JEL-Classification: C93, D03, Q01, Q50.

\footnotetext{
*Acknowledgements: We thank Guy Meunier, Nicolas Treich as well as participants at the workshop on "Behavioral experimental economics" in Toulouse, the ESA North-American meeting in Fort Lauderdale and the Workshop on Natural Experiments and Controlled Field Studies in Ohlstadt for helpful thoughts and comments. Also, we thank the buildings insurance of the Kanton of Zurich $(\mathrm{GVZ})$ for their assistance. Financial support is acknowledged from the Swiss Federal Office of Energy.

${ }^{\dagger}$ University of Konstanz and Thurgau Institute of Economics, Post Box 131, 78457 Konstanz, Germany

Urs.Fischbacher@uni-konstanz.de

†Department of Economics, University of Munich, Geschwister-Scholl-Platz 1, D-80539 Munich, Germany, e-mail: simeon.schudy@econ.lmu.de

${ }^{\S}$ INRA, UR 1303 ALISS, 65 bd de Brandebourg, F-94200 Ivry-sur-Seine, France, and Ecole Polytechnique (Dept. Economics), Palaiseau, France. Sabrina.Teyssier@ivry.inra.fr
} 


\section{Introduction}

The building stock of EU member states accounts for over $40 \%$ of EU's final energy consumption. EU's residential energy use represents $63 \%$ of total energy consumption (see Balaras et al., 2007) and, similarly, the US residential sector ${ }^{5}$ strongly impacts total energy use and greenhouse gas emissions (Eichholtz et al., 2010; Eichholtz and Quigley, 2012; Royal Institution of Chartered Surveyors, 2005). However, according to several studies, the building sector also offers large possibilities for greenhouse gas abatement (Bardhan et al., 2014; Enkvist et al., 2007; Evans et al., 2011; Intergovernmental Panel on Climate Change, 2007; Levine et al., 1995; Stern, 2008). If more investments in energy saving measures are realized, energy consumption can be considerably reduced (see e.g. Gillingham and Palmer, 2014; McKinsey \& Co, 2009). Why then do we observe large heterogeneity in energy investments across homeowners? Why do many homeowners appear to be reluctant to invest in energy saving measures? The aim of this paper is to provide a better understanding of differences in homeowners' investment behavior (and energy consumption) by relating it to the heterogeneity in homeowners' individual preferences.

From an economic point of view, homeowners' potential underinvestment in energy efficiency measures (i.e. an "energy-efficiency gap" between actual and the individually optimal investment) results from investment inefficiencies and externalities (Allcott and Greenstone, 2012; Hausman, 1979; Jaffe and Stavins, 1994). ${ }^{6}$ Investment inefficiencies arise if homeowners do not fully consider the earnings associated to investments in energy saving measures, for instance,

\footnotetext{
5 The U.S. Energy Information Administration defines the "residential sector" as an energy-consuming sector that consists of living quarters for private households. Energy use in this sector includes space heating, water heating, air conditioning, lighting, refrigeration, cooking, and running a variety of other appliances. The residential sector excludes institutional living quarters (see http://www.eia.gov/dnav/pet/tbldefs/pet_pri_prop_tbldef2.asp).

${ }^{6}$ There is an ongoing debate between economists and engineers on the size of this gap. Many economists argue that costs of investment in energy saving measures are neglected or underestimated due to individuals' behavioral considerations. Hence, the cost-benefit analysis of these energy-efficient investments may lead to over-estimate the energy-efficiency gap (Allcott and Greenstone, 2012; Gillingham and Palmer, 2014; Metcalf and Hassett, 1999; Smith and Moore, 2010).
} 
because they are imperfectly informed or present biased. ${ }^{7}$ Externalities refer to the fact that homeowners may not internalize benefits of their investments for others, i.e. for human health and the environment. ${ }^{8}$ Homeowners are likely to be heterogeneous in the degree of their investment inefficiencies (Allcott and Greenstone, 2012) as well as in the internalization of externalities. In addition, homeowners are likely to differ with respect to other important aspects that may matter for investments in energy saving measures and consumption. First, energy investments generate uncertain benefits. Second, benefits from renovations occur in the future and costs arise in the present. If homeowners differ in their risk and time preferences, the differences in individual investments in energy efficiency measures may result from the differences in homeowners' risk attitudes and time preferences. ${ }^{9}$

The aim of this study is to broaden the understanding of homeowners' investments in energy efficiency measures by studying how heterogeneity in individual preferences drives differences in homeowners' investment behavior. The contribution of this study is twofold. First, we provide insights on how individual measures of risk, time, social and environmental preferences relate to the renovation decision of homeowners. Second, we shed light on how these preference measures relate to homeowners' energy consumption behavior. Our approach elicits preferences of single family homeowners (who live in their house) by combining methods from experimental economics with survey questions. By relating these measures to homeowners'

\footnotetext{
${ }^{7}$ See also Epper et al. (2011).

${ }^{8}$ See for instance Achtnicht (2011), who identifies environmental benefits as potential drivers of homeowners' investment in energy saving measures and Gowdy (2008) who suggests that social impacts relate to energy investments.

9 There is a strong indication that risks associated with energy saving investments are central in the renovation decisions (Farsi, 2010; Hassett and Metcalf, 1993; Metcalf and Hassett, 1999). Also Epper et al. (2011) report that households explicitly state that they are uncertain about future energy costs which is a driving factor in the investment decision. Andreoni and Sprenger (2012) show with experimental data that risk preferences and time preferences are different. Their study suggests that if future earnings (or costs) are uncertain (as compared to present earnings or costs that are certain) both risk and time preferences must be considered. Newell and Siikamaki (2015) find a positive relation between preferences for energy efficiency (measured by hypothetical water heater choice tasks and federal energy efficiency tax credit claims) and individual discount factors (measured in a non-incentivized choice task, in which study participants choose between a hypothetical tax-free cash credit check of $1000 \$$ to be received in one month or a higher tax free credit to be received in 12 months).
} 
renovation and energy consumption behavior our work further contributes to studies that relate incentivized preference measures used in laboratory experiments to real world behavior outside of the lab (see e.g. Benz and Meier, 2008; Chabris et al., 2008; De Oliveira et al., 2012; Dohmen et al., 2011). Such studies are essential to judge the generalizability of preference measures used in laboratory experiments.

The novelty of our study design is that it relates a set of directly elicited individual preference measures to homeowners' investments in increasing energy efficiency and homeowners' energy consumption behavior. Our set of individual preference measures consists of a measure of risk preferences, which is obtained using the experimentally validated risk questionnaire proposed by Dohmen et al. (2011), homeowners' individual discount factor (elicited using an incentivized individual decision task, in which they decide between a lower payment in the near future and higher payments in the far future), homeowners' social preferences (obtained using incentivized dictator and generosity games), and homeowners' preferences for the environment, which we elicit using a set of items based on the New Environmental Paradigm Scale (Dunlap and Van Liere, 1978).

The results of our study show that risk preferences are particularly important for the decisions to renovate houses. We find that the renovation decision is perceived as risky: homeowners who are more likely to take risks in general or in financial matters are more likely to have their house renovated. ${ }^{10}$ Among renovators, we find that homeowners' discount factors and pro-environmental preferences relate positively to the energy efficiency of the house, i.e. renovators who value the future particularly strongly or reveal pro-environmental preferences own houses with higher energy quality. However, time preferences and environmental preferences seem to play no role for the renovation decision. Furthermore, we find that environmentally friendly and more future oriented homeowners consume less energy (controlling for the energy

${ }^{10}$ Qiu et al. (2014) find a similar relationship between risk and investments using a framed hypothetical lottery choice task. 
efficiency of their house). The findings on social preferences are mixed. While social preferences do not relate to the renovation decision, renovators who are generous with their own money (in an incentivized Dictator Game) have a higher estimated energy quality whereas renovators who are generous when it is costless (in an incentivized Generosity Game) have houses with lower estimated energy quality.

In contrast to our approach, previous research has mainly relied on average estimates of utility function and implicit discount rates (Alberini et al., 2013; Hausman, 1979; Train, 1985) or has studied preference measures in isolation (see Qiu et al., 2014). To the best of our knowledge, only the study by Qiu et al. (2014) allows for heterogeneous risk preferences when explaining individuals' decisions to invest in energy efficiency measures. In contrast to our approach, the authors elicit risk preferences with framed hypothetical lottery choices (similar to the approach by Holt and Laury, 2002) where each lottery is described as a different investment opportunity. In line with our results, Qiu et al. (2014) find that more risk averse individuals are less likely to make energy efficient investments. By measuring risk attitudes using the experimentally validated risk questionnaire proposed by Dohmen et al. (2011) and additionally introducing incentivized measures for individual time and social preferences (as well as an individual measure for homeowners' environmental preferences) we complement and broaden the analysis by Qiu et al. (2014). Our broader set of preferences measures enables us to study how heterogeneity in different preference dimensions affects homeowners' investment behavior.

Our results also provide insights for the design of policy interventions. Traditional policies fostering energy efficient renovations have focused on monetary incentives such as tax reductions and subsidies (see e.g. Alberini and Filippini, 2011). In addition to monetary incentives researchers have recommended to promote the diffusion of information about technologies and economics of energy efficiency renovations as well as the assignment of energy efficiency renovation specialists (Banfi et al., 2010). We find heterogeneity in individuals' risk, time, social 
and environmental preferences, which is reflected in their investments in energy efficiency measures and energy consumption. Such heterogeneity suggests targeted policies (see also Allcott and Greenstone, 2012; Golove and Eto, 1996) and weakens the policy argument for simply subsidizing energy efficient goods (see Allcott et al., 2014). ${ }^{11}$ Our results further demonstrate that renovation decisions are indeed perceived as a risky decision, whereas the extent of the renovation depends more on homeowners' time and environmental preferences. Policies should therefore aim at reducing the (perceived) risk of renovations and provide gains for renovators as early as possible. One way to reduce the (perceived) risk is to provide households with future earnings “guarantees”. E.g. governments or energy providers could engage in supporting energy efficient renovations by sharing the costs and risk but also the benefits from future savings.

The remainder of this paper is organized as follows. In Section 2, we briefly present the theoretical framework introduced by Allcott and Greenstone (2012) and derive our main hypotheses concerning the relation between individual preferences and energy investment and consumption behavior. We explain the data collection procedure in Section 3 and describe the data set we use for the analysis in Section 4. Results are presented in Section 5. Section 6 concludes.

\section{Theoretical framework and hypotheses}

To provide some structure, we briefly describe the theoretical framework we have in mind when deriving our hypotheses concerning investments in energy saving measures. The framework is based on the model of investment in energy efficiency measures developed by Allcott and Greenstone (2012). We assume that energy efficiency investments are associated with present costs and future benefits. To simplify, consider the case in which individuals exist only in two periods: in the first period they decide whether or not to invest in energy efficiency and choose the amount of their investment. In the second period, homeowners incur energy costs and minimize

\footnotetext{
${ }^{11}$ Bento et al. (2012) also show that ignoring heterogeneity in individuals' preferences leads to biased estimates of future energy savings following an investment in energy saving measures.
} 
these costs for a given level of comfort, i.e. a given level of utility. ${ }^{12}$ In the first period, each individual compares her expected utility of future savings in terms of energy costs $\left(E U_{\alpha}\right)$ to the immediate cost of investment in energy-saving measures $C(q)$. The individual chooses to invest only if the expected utility of the investment outweighs the direct cost of the investment:

$$
E U_{\alpha}(\delta, \gamma, p, \Delta E(q))>C(q)
$$

$E U_{\alpha}(\delta, \gamma, p, \Delta E(q))$ depends on the individuals discount factor $\delta$, her internalization of externalities (i.e. her preferences for the environment and social preferences) $\gamma$, energy prices $p$ and the potential energy savings $\Delta E(q)$, which occur in the future and are uncertain. The parameter $q$ indicates the energy efficiency quality of the house which increases the direct costs of the investment $C(q)$ as well as the energy savings $\Delta E(q)$. The energy savings $\Delta E(q)$ correspond to the difference between the energy intensity of the house, if it has not been renovated $E_{N R}$, and the uncertain energy intensity of the house if it has been renovated $E_{R}(q)$, which decreases in the quality of the renovation $q .13$ The individual knows that $E_{R}(q)<E_{N R}$ for $q>0$ but, nevertheless, the difference $\Delta E(q)$ is uncertain. The parameter $\alpha$ reflects the individual's risk aversion. $E U_{\alpha}$ decreases with risk aversion $\alpha$, as the future energy intensity is uncertain. The individual's psychological discount factor $\delta$ also affects expected utility. The stronger an individual discounts the future (the smaller $\delta$ ), the lower will be her expected utility. ${ }^{14}$ Further, as the individual puts more weight on the welfare of others or the environment (higher $\gamma$ ), her expected utility of the investment increases. This basic framework yields the following hypotheses concerning the investment behavior of homeowners:

\footnotetext{
${ }^{12}$ Note that we suppose here that the objective regarding the level of utility to attain in the second period does not change depending on the individual's decision in the first period. This assumption might be violated if people overconsume after they have invested in energy efficiency in the first period. This may be the case if green technologies (e.g. solar panels) are not only be seen as an investment but also provide an additional consumption values for "green" consumers (see Dastrup et al., 2012).

13 Note that we abstract here from the fact that future energy prices themselves are uncertain. If we would allow for future prices to be uncertain also $E_{N R}$ is uncertain. Clearly Hypothesis 1 stems on this assumption.

${ }^{14}$ The interest rate is taken into account with $\delta$ representing the individual's discount factor net of the interest rate.
} 
H1: Less risk averse homeowners are more likely to invest in energy efficiency.

H2: More future-oriented homeowners are more likely to invest in energy efficiency.

H3: Pro-environmental homeowners are more likely to invest in energy efficiency.

H4: Pro-social homeowners are more likely to invest in energy efficiency.

Energy consumption in the second period yields certain present costs and benefits. However, energy consumption affects others and the environment. We therefore expect that proenvironmental and pro-social homeowners consume less energy.

H5: Pro-environmental and prosocial homeowners consume less energy.

\section{Data collection and methodological aspects}

Our study focuses on Swiss homeowners. Although Switzerland is one of the most advanced countries with respect to energy efficiency among OECD countries (Evans et al., 2011) there is an important potential to reduce greenhouse emissions in the Swiss housing market. Jakob and Madlener (2004) report that energy use for space heating may be reduced by $33-50 \%$ in existing buildings and by $80 \%$ or more in new buildings. Jochem et al. (2003) indicate that only few Swiss homeowners invest in renovating building envelopes, which may contribute substantially to improvements of buildings' energy efficiency. ${ }^{15}$ Although Banfi et al. (2008) provide evidence that the willingness to pay for building efficiency enhancements exceeds the cost of implementing these measures, homeowners in Switzerland are reluctant to invest in energy saving by retrofitting their building envelopes and do so mainly at the end of the building element's lifetime (see Jakob, 2007).16 In turn homeowners may forgo profitable investments.

\footnotetext{
${ }^{15}$ For further information see also (Jochem and Jakob, 2004), who provides a detailed analysis of energy perspectives on $\mathrm{CO}_{2}$ reduction potentials in Switzerland up to 2010.

${ }^{16}$ It has also to be noted that not all building efficiency enhancements exceed the cost of implementation. For instance, Scarpa and Willis (2010) provide results which suggest that households' value of renewable energy adoption is not sufficient to cover the higher capital costs of micro-generation energy technologies such as solar-panels in the UK.
} 
We collected the data in German-speaking Swiss cantons. First, we contacted 2500 homeowners in the canton of Zurich with the help of the canton of Zurich buildings insurance (GVZ). Second, we directly contacted 2139 additional households outside the canton of Zurich but within the German-speaking cantons of Switzerland (to avoid approaching the same homeowners twice). We received a total of 550 completed questionnaires, 264 in the canton of Zürich and 286 in other cantons. ${ }^{17}$ The response rate was about 12 percent. To minimize barriers for energy investments such as incentive conflicts between tenants and homeowners (Clinch and Healy, 2000; Golove and Eto, 1996; Levinson and Niemann, 2004)18 we focus our analysis on homeowners of single family houses who also live in their house, who are most likely to benefit themselves from investments in energy efficiency measures (489 homeowners in total).

Homeowners were asked to answer questions on the energy quality of their house depending on three factors: window quality, roof quality and façade quality. They also had to indicate whether they did renovate their house in the past and whether they plan future renovation. Further we asked for the age and size of their house. For a subsample of households, we additionally elicited information about energy consumption.

To control for the financial situation of homeowners, we included questions from the German SAVE study (see Boersch-Supan and Essig, 2005) in our questionnaire. The questions focus on how much money is available at the end of a month and thereby indirectly and non-intrusively elicit a proxy for homeowners' wealth. ${ }^{19}$

Homeowners' time preferences and social preferences (i.e. preferences for generosity and equality) were elicited using incentivized pen and paper experiments. Homeowners' preferences

${ }^{17}$ A translated version of the letter sent to homeowners including the questionnaire and the experimental decision tasks is available in the Online Appendix.

${ }^{18}$ For a further discussion of barriers and drivers of energy efficient renovations that are different from individual preferences, for instance retrofit costs or future energy prices, see Cameron (1985), who provides an early study that analyzes house retrofit decisions with data from the U.S. More recent studies highlight and discuss such barriers for Switzerland (Banfi et al., 2008), Canada (Sadler, 2003) the Netherlands (Poortinga et al., 2003), South Korea (Kwak et al., 2010), Sweden (Nair et al., 2010) and Germany (Achtnicht and Madlener, 2014).

${ }^{19}$ It has been shown that answers to these questions correlate highly with personal wealth (see Boersch-Supan and Essig, 2005, p.33). 
with respect to risk were elicited using experimentally validated risk questionnaire proposed by Dohmen et al. (2011). ${ }^{20}$ Homeowners' preferences for the environment were elicited using a set of items based on the New Environmental Paradigm Scale (Dunlap and Van Liere, 1978).

All participants of the study had the possibility to earn money by participating. Payments depended on the decisions made in the different incentivized choice tasks (Dictator Game, Generosity Game, Time Preferences elicitation task), of which one was randomly selected to be paid. To ensure trust in the random selection of the payoff-relevant decision, we assigned a twodigit number to each decision which was linked to last digits of the Swiss public lottery (Joker). ${ }^{21}$ On average, payments amounted to 40 Swiss francs. Participants received their payment via bank transfer or mail about one month after we received the questionnaire (and were informed about this procedure). ${ }^{22}$ In the two following sections, we present the obtained measures for energy efficiency investments, risk, time, environmental and social preferences in more detail.

\section{Data description}

\subsection{Background information}

The sample used in the analysis encompasses a total of 342 participants. ${ }^{23}$ The age of houses ranges from 2 to 405 years with a median of 17 years (standard deviation $=43.05$ ). In order to cope with the possibility of a non-linear relationship between house age and renovation behavior,

\footnotetext{
20 Dohmen et al. (2011) find that answers to the general risk attitude question predict actual behavior in lottery tasks with safe options.

${ }^{21}$ As mentioned above, we conducted two waves. In the first wave, on average every fourth participant received a variable amount determined by her own or some other participant's decision in one of the decision tasks. In the second wave, every participant received a fixed payment of 10 Swiss francs for participating plus a variable amount that was determined by the participants' decision in the choice task. We did so, as some participants in the first wave complained about the fact that not everyone was paid. As intended, this slightly increased the response rate (from 11 percent to 13 percent).

${ }^{22}$ Payments were delayed for a month to ensure that participants made all decisions in the same "risk-in-time" environment as in the time preference task, they received their payment either 1 or 7 months after the reception of their questionnaire.

23 The reduction of the sample size to 342 homeowners results for two reasons. First, we only use the data of homeowners living in their own house, who made all decisions in the preference elicitation tasks and answered all questions that are used in the analysis. Additionally, we restrict the analysis to those participants who made consistent choices in the time preference tasks (e.g. we excluded homeowners who preferred 80.50 in 7 months over 80 in 1 month but preferred 80 in 1 month over 81 in 7 months).
} 
we generated four house age classes, based on a quartile split $\left(1^{\text {st }}\right.$ quartile $=14$ years, $2^{\text {nd }}$ quartile $=17$ years, $3^{\text {rd }}$ quartile $=32$ years $) .{ }^{24}$ The size of houses ranges from 44 square meters to 2400 ( median=170; std. deviation=160.72). Concerning households' financial situation, we asked individuals to answer the following question: "If you think back to how you (and your partner) managed on with your income in 2010: What describes the situation best?" Homeowners could tick one of the following options "At the end of the month there was lots of money left", "At the end of the month there was frequently some money left", "There was only money left, if a nonrecurring income occurred", "At the end of the month it was often not enough", or "At the end of the month it was never enough" (see also Boersch-Supan and Essig, 2005). Only 2\% of participants have either often not enough or never enough money at the end of the month, $12 \%$ have money left only if a nonrecurring income occurred and $86 \%$ have either frequently some money left or lots of money left.

\subsection{Measures of energy investments}

Our main analysis focuses on energy investments. As explained in the theoretical framework, we understand the investment decision as deciding whether or not to renovate and if so, to what extent to invest in energy efficiency. Thus, we analyze energy investments in several ways. First, we elicited general past and future renovation behavior by asking for the year of the last renovation of the house and whether a future renovation is planned. In total, $42.4 \%$ of houses are renovated, $23.7 \%$ of houses are planned to be renovated (including $13.2 \%$ already renovated), $47.1 \%$ of houses are not renovated and not planned to be renovated. Second, participants were asked to rate the energy efficiency of their house. Homeowners evaluate the quality of their windows, roof and façade on a four point scale by answering questions similar to those used in Banfi et al. (2008). Table 1 shows the share of respondents for each category of the quality variables. The majority of respondents have standard insulated windows as well as standard roof and façade quality. Around

\footnotetext{
${ }^{24}$ Each class includes its upper bound.
} 
one quarter of homeowners attribute enhanced insulation with respect to window quality. One third reports enhanced roof and façade quality. Less than 10 percent report the lower two quality categories for each of the three measures.

Table 1: Window, roof and façade quality

\begin{tabular}{|c|c|}
\hline & Percent of respondents $(n=342)$ \\
\hline \multicolumn{2}{|l|}{ Window quality } \\
\hline Enhanced window & 23 \\
\hline Standard insulated ${ }^{25}$ & 73 \\
\hline Medium old window & 4 \\
\hline Very old window & 0 \\
\hline \multicolumn{2}{|l|}{ Roof quality } \\
\hline Enhanced roof insulation & 32 \\
\hline Standard roof insulation ${ }^{26}$ & 61 \\
\hline Medium old roof insulation & 5 \\
\hline Very old roof insulation & 2 \\
\hline \multicolumn{2}{|l|}{ Façade quality } \\
\hline Enhanced façade insulation & 32 \\
\hline Standard insulation ${ }^{27}$ & 58 \\
\hline Repainted façade & 6 \\
\hline Old facade & 4 \\
\hline
\end{tabular}

To obtain a proxy for the global energy efficiency of the house, we create an index variable aggregating the window, roof and façade quality. As these three types of quality characteristics may not have the same weight for households' overall appreciation of house quality, we estimate the weight of each characteristic using a question on the general subjective energy efficiency of participants' homes measured on a 5-point Likert scale (very low, low, medium, high and very high). Using households subjective evaluations of efficiency (mean $=3.35$, std. deviation $=0.65)^{28}$ we estimate how homeowners weight the importance of window, roof and façade quality for the efficiency of their house. We regress the subjective efficiency measure on window, roof and facade quality. As Table 2 shows, homeowners attribute on average slightly stronger weights to roof quality and window quality than to façade quality. Using the regression results, we calculate for each household the estimated overall quality of the house (estimated overall quality $=0.279 *$

\footnotetext{
${ }^{25}$ Standard window refers to coated window glass with complete gasket.

${ }^{26}$ Participants could choose among very good, "normal" (standard), medium old and old insulation.

${ }^{27}$ Participants had no additional information on façade insulation other than reported in the table.

${ }^{28}$ About $51 \%$ of homeowners rate their house as medium- efficient and about $39.3 \%$ as highly so. $7.1 \%$ consider the efficiency of their house as low, $1.8 \%$ as very high and $0.3 \%$ as very low.
} 
roof quality $+0.217 *$ window quality $+0.368 *$ façade quality +0.590$)$. The estimated overall quality ranges from 1.67 and 4.05 (mean=3.35, std. deviation=0.42).

Table 2: OLS estimation of subjective energy efficiency of the house ${ }^{29}$

\begin{tabular}{lc}
\hline \hline & Subjective energy efficiency \\
\hline Roof quality & $\mathbf{0 . 3 6 8 * * *}$ \\
& $(0.051)$ \\
Window quality & $\mathbf{0 . 2 7 9} * * *$ \\
& $(0.054)$ \\
Constant & $\mathbf{0 . 5 9 0 * * *}$ \\
& $(0.213)$ \\
Façade quality & $\mathbf{0 . 2 1 7} * * *$ \\
& $(0.065)$ \\
\hline Observations & 336 \\
R-squared & 0.413 \\
\hline \hline
\end{tabular}

Note: cluster-robust standard errors in parentheses (clustered on postal code), $* * * \mathrm{p}<0.01, * * \mathrm{p}<0.05, * \mathrm{p}<0.1$

\subsection{Measures of individual preferences}

\subsubsection{Risk preferences}

We measure risk preferences using the experimentally validated questionnaire by Dohmen et al. (2011). The risk questionnaire allows participants to indicate their willingness to take risks in general and context specific risks. ${ }^{30}$ Participants tick a box on a five point scale ranging from "not ready to take risks" (value 1) to "very risk-taking" (value 5). Figure 1 presents the distribution of participants' answers to the risk task.

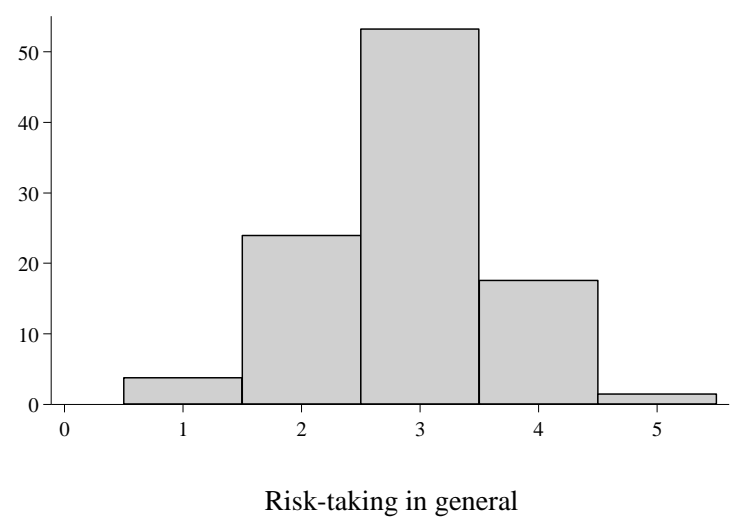

Figure 1: Risk-taking in general $(\mathrm{n}=342$, not risk seeking=1, very risk seeking=5).

\footnotetext{
${ }^{29}$ Six subjects did not indicate a subjective level of the efficiency of their house. We do not use these six homeowners to construct the overall efficiency measure of the house. However, as all six subjects have indicated the façade, window and roof quality of their house, we calculate the overall efficiency of their house using the weights from the estimation shown in Table 2 (as for all other participants).

${ }^{30}$ They were also asked for their risk attitudes in different contexts such as risk-taking in financial matters, car driving, leisure and sports, and professional career. We will report in the analysis the effect of risk-taking in general on energy saving investments. Nevertheless, we found similar effects of risk-taking in financial matters, but not for risk-taking in car driving, leisure and sports, and professional career.
} 


\subsubsection{Time Preferences}

Our measure of homeowners' time preferences is based on 11 decision situations in which homeowners had to decide whether they wanted to receive 80 Swiss francs in one month or a higher amount in seven months. The amounts available in the more distant future (i.e. in seven months) ranged from 80.50 Swiss francs to 108 Swiss francs. A person values future payments more strongly, the lower the monetary amount at which the person switches to the payment in the far future is. ${ }^{31}$ For the analysis we focus on homeowners' minimum discount factor, i.e. $\frac{\text { amount in one month }}{\text { amount in seven month }}$, at which the respondent chooses the future amount for the first time. The distribution of participants' discount factors is provided in Figure 2.32

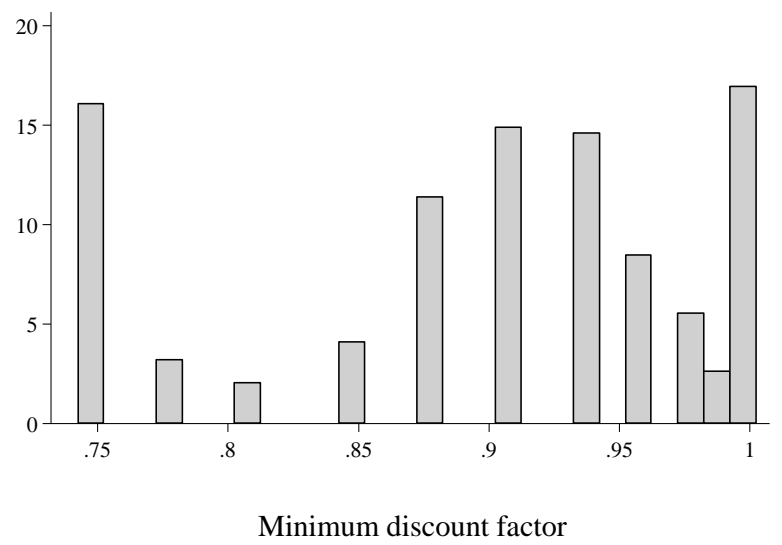

Figure 2: Minimum discount factors $(n=342)$.

\subsubsection{Environmental preferences}

We measure environmental preferences with questions from a questionnaire on environmental preferences based on the New Environmental Paradigm Scale (Dunlap and Van Liere, 1978). Participants were asked to state their agreement with the following three statements (on a 5-point scale): "We are approaching the limit of the number of people the earth can support", "To survive, people have to live in harmony with nature", and "People do not have to adapt to nature, because they can restore it." We built an index on the following three statements by adding positively

\footnotetext{
${ }^{31}$ For a critical review on discounting and time preferences see also Frederick et al. (2002).

32 As a further proxy for time preferences we also calculated the number of choices in favor of receiving the payment within a month. The results are similar to those obtained using the minimum discount factor.
} 
framed questions and subtracting negatively framed questions. The obtained environmental preference index then ranges from 0 to 9 . Figure 3 presents the distribution of individuals' environmental preference index.

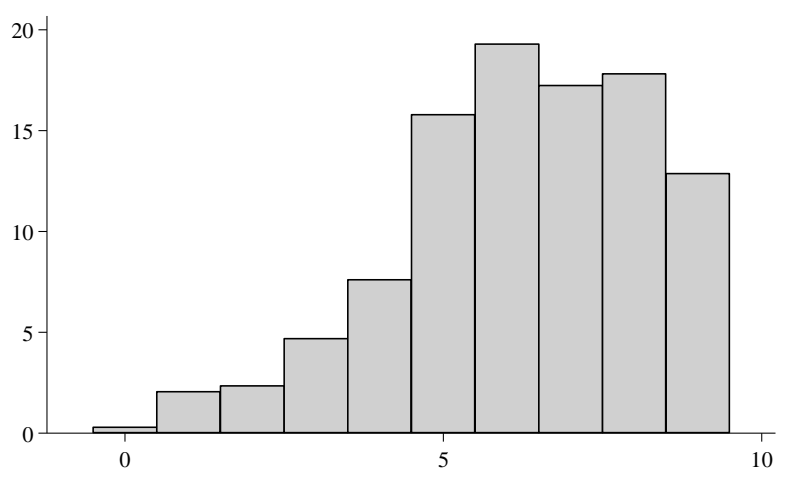

Environmental Preference Index

\section{Figure 3: Environmental preference index $(n=342)$}

\subsubsection{Social preferences}

We used two experiments to measure social preferences. In the first experiment (Generosity Game) we measure generosity when being generous is costless. The participant receives a fixed amount and can decide how much another person will receive from the experimenter. In the second experiment, we focus on generosity which is costly. Participants decide in a dictator game how to share a fixed total amount of money between themselves and another participant.

\section{The generosity game (Generosity)}

Homeowners play a two person generosity game in which the first player receives a fixed payoff of $\mathrm{X}$ and can decide on the payoff $\mathrm{Y}$ for the second player, with $Y \in[X-d, X+d]$ and $d \geq 0$, keeping his own payoff constant. The higher the value of $\mathrm{Y}$, the more generous we consider a player. Very generous persons or persons with preferences for efficiency (in the sense of maximum total payoff for the two players) choose to give the maximum amount to the other person. Note that the game also measures inequality aversion, as inequality averse participants 
may refuse to give an amount higher than $\mathrm{X}$ to the second person. ${ }^{33}$ Figure 4 shows histograms for the share allocated to the other player. As can be seen in Figure 4 our generosity measure splits the main part of our sample into two types of behavior: inequality averse participants chose the same amount for the second participant whereas generous participants chose the highest possible amount.

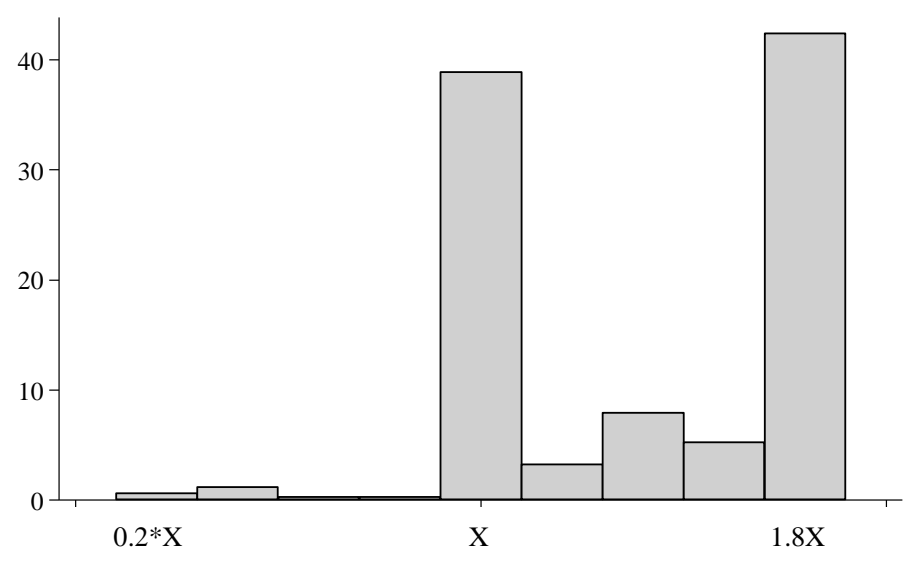

Share for other player in Generosity Game

\section{Figure 4: Share for other participant in the generosity game} ( $\mathrm{n}=342, \mathrm{X}=$ decision maker's payoff)

\section{The dictator game (Fairness)}

We used a dictator game in order to measure social preferences in an environment where being prosocial is costly. In the dictator game, player 1 receives an amount of money $\mathrm{Z}$ which she can distribute between herself and another player. In our Dictator Game, the minimum share player 1 can allocate to a player is restricted to 10 percent of Z. ${ }^{34}$ Figure 5 shows a histogram for the share of $\mathrm{Z}$ allocated to the other player. More than 60 percent of participants establish perfect equality. ${ }^{35}$ The second largest fraction of participants chooses the selfish option.

33 In the experiment: $d=0.8 \mathrm{X}$ with $\mathrm{X}=100$ Swiss francs for the households in the first wave and $\mathrm{X}=50$ for households in the second wave (as the latter households received a flat payment of 10 Swiss francs for participating).

${ }^{34} \mathrm{Z}=100$ Swiss francs for the households in the first wave and 50 Swiss francs for households in the second wave (as the latter households received a flat payment of 10 Swiss francs for participating).

35 As already documented by Engel (2011), also our non-student subjects give much more than usual student subjects. 


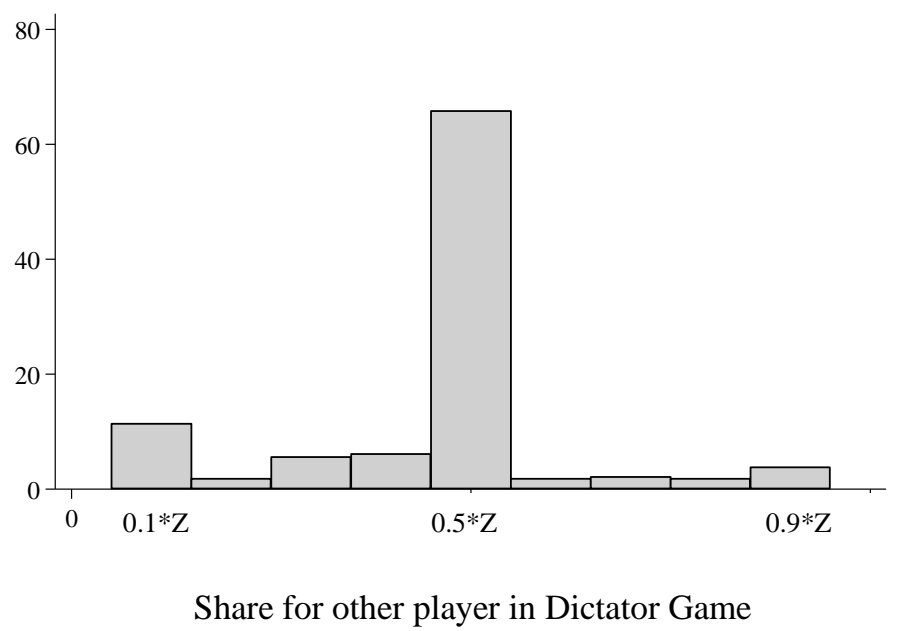

\section{Figure 5: Share for other participant in the dictator game} ( $\mathrm{n}=342, \mathrm{Z}=$ pie to be divided among the two players)

\section{Results}

A natural way to think about a renovation decision is to assume that households first decide on whether or not to renovate at all and second, they decide on the exact enhancements they want to achieve by retrofitting their home. Therefore, we first focus on the decision to renovate the house at all and second analyze how the energy quality of the house relates to preferences contingent on renovation activity. Previous studies have shown that social norms impact households' decisions in energy conservation (Allcott, 2011; Baddeley, 2011). Therefore house energy quality as well as renovation behavior of different homeowners may be correlated for houses that are geographically close. To cope with this issue we will use cluster-robust standard errors with clustering on postal codes in all of our regressions. ${ }^{36}$

In Section 5.1 we analyze how preferences relate to the renovation decision of homeowners. In Section 5.2 we study the impact of respondents' preferences on the energy efficiency of the house. Finally, in Section 5.3 we discuss the results and shed light on how preferences affect energy consumption behavior.

\footnotetext{
${ }^{36} \mathrm{We}$ also ran the analysis with clustering on cantons and without clustering. The results are qualitatively similar.
} 


\subsection{Renovation decision}

Table 3 presents results from probit regressions explaining participants' decisions to renovate. In Model (1) we estimate the probability of having renovated in the past. In Model (2) we estimate the probability that participants have renovated in the past or plan to renovate in the future. Explanatory variables are the preference measures presented in the previous section: general risk preferences, time preferences, environmental preferences, as well as generosity and fairness preferences. ${ }^{37}$ Model (3) and Model (4) replicate models (1) and (2) respectively controlling for the age of the house and its size in square meters. ${ }^{38} \mathrm{We}$ also control for the financial position of the participant.

Table 3: Decision to renovate

\begin{tabular}{|c|c|c|c|c|}
\hline & (1) & (2) & (3) & (4) \\
\hline & $\begin{array}{c}\text { Past } \\
\text { renovation }\end{array}$ & $\begin{array}{l}\text { Past or future } \\
\text { renovation }\end{array}$ & Past renovation & $\begin{array}{l}\text { Past or future } \\
\text { renovation }\end{array}$ \\
\hline \multirow[t]{2}{*}{ Risk-taking (from 1 to 5) } & $0.059 *$ & $0.056 * *$ & $0.061 * *$ & $0.050 *$ \\
\hline & $(0.032)$ & $(0.026)$ & $(0.030)$ & $(0.030)$ \\
\hline \multirow[t]{2}{*}{ Discount factor (from 0.747 to 1 ) } & 0.139 & 0.170 & -0.038 & -0.026 \\
\hline & $(0.352)$ & $(0.305)$ & $(0.468)$ & $(0.360)$ \\
\hline \multirow[t]{2}{*}{ Pro-environmental (from 0 to 9) } & 0.015 & 0.015 & 0.001 & 0.006 \\
\hline & $(0.009)$ & $(0.010)$ & $(0.011)$ & $(0.013)$ \\
\hline \multirow[t]{2}{*}{ Generosity (from 0.1 to 0.9 ) } & 0.076 & $0.200 *$ & -0.164 & 0.030 \\
\hline & $(0.099)$ & $(0.114)$ & $(0.127)$ & $(0.142)$ \\
\hline \multirow[t]{2}{*}{ Fairness (from 0.1 to 0.9 ) } & $-0.239 * *$ & $-0.210 * *$ & -0.017 & 0.005 \\
\hline & $(0.100)$ & $(0.105)$ & $(0.128)$ & $(0.134)$ \\
\hline \multirow[t]{2}{*}{ 14-17 year old house } & & & 0.022 & -0.004 \\
\hline & & & $(0.073)$ & $(0.066)$ \\
\hline \multirow[t]{2}{*}{ 18-32 year old house } & & & $0.380 * * *$ & $0.338 * * *$ \\
\hline & & & $(0.062)$ & $(0.049)$ \\
\hline \multirow{2}{*}{ House older than 32 years } & & & $0.670 * * *$ & $0.570 * * *$ \\
\hline & & & $(0.034)$ & $(0.041)$ \\
\hline \multirow[t]{2}{*}{ Log(House size $)$} & & & 0.008 & 0.092 \\
\hline & & & $(0.08)$ & $(0.071)$ \\
\hline \multirow[t]{2}{*}{ Good financial position (from 1 to 3 ) } & & & -0.011 & 0.014 \\
\hline & & & $(0.121)$ & $(0.093)$ \\
\hline Observations & 342 & 342 & 342 & 342 \\
\hline \# of clusters & 167 & 167 & 167 & 167 \\
\hline Pseudo R-squared & 0.0159 & 0.0181 & 0.273 & 0.232 \\
\hline
\end{tabular}

\footnotetext{
${ }^{37}$ Note that we rescaled the share for the other participant in the Generosity Game such that the decisions range, as in the Dictator Game, from 0.1 to 0.9 .

${ }^{38}$ See also Chong (2012) analyzes the relation between the age of a house and its electricity consumption when temperatures change and Brounen et al. (2012), who investigate whether dwelling characteristics or the demographic characteristics of households (e.g. household composition and income).
} 
The regressions in Table 3 show that among our preference measures individuals' risk preferences are the main driver of past renovations. Participants who declare being more risk seeking have a higher probability of having had their house renovated in the past. Risk preferences relate in the same way to future renovation plans. In line with Hypothesis 1 the results indicate that households perceive renovations as risky investments that yield uncertain returns but entail certain costs at the time of the investment decision. ${ }^{39}$ Time and pro-environmental preferences do not significantly relate to the renovation decision. Fairness and generosity appear significant in model specifications (1) and (2) but turn out to be statistically insignificant when further controls are taken into account (see models (3) and (4)). As already observed e.g. by Alberini et al. (2011), older houses are more likely to have been renovated.

\section{Result 1: Homeowners who are more likely to take risks are more likely to renovate.}

\subsubsection{Energy efficiency of the house}

In the following we present results on how individual preferences relate to the energy quality of the house. We report results from OLS regressions explaining the estimated overall quality of the house in Table 4. In models (1) and (2), we regress the estimated overall quality of the house based on risk, time, environmental, and social preferences (generosity and fairness preferences). In models (3) and (4), we add the age and size of the house and participants' financial position as additional controls. In models (1) and (3), we consider all households. If we think about a renovation decision as a two-step procedure in which households first decide on whether or not to renovate and second, decide on the exact enhancements they want to achieve by retrofitting their home, it is worthwhile to investigate whether heterogeneity of preferences can explain the efficiency of houses among renovators separately. Therefore, in models (2) and (4), we restrict the analysis to households who already renovated their house. Additionally we run a Heckman

39 As mentioned earlier, we also elicited risk attitudes in specific domains. Conducting the same econometric analysis using domain specific risk measures (available on request) shows that people who are more willing to take risks in financial matters or in their career are more likely to renovate whereas risk attitudes in car driving or sports do not relate significantly to the renovation decision. 
selection analysis in Model (5), which takes the potential selection of homeowners who renovated into account. Result 1 has shown that the more risk-taking homeowners are, the higher is the probability that they invest in a renovation. In turn, models (1) and (3) in Table 4 indicate that participants who are more risk-taking have a higher estimated overall home quality with respect to energy efficiency. Models (2) and (4) shed some light on households who decided to renovate their house. For renovators, the estimated overall quality increases in their discount factor. The Heckman selection Model (5) shows that risk taking is important for the decision to renovate (selection) but discount factors significantly relate to the estimated efficiency of the house. In line with Hypothesis 2, more future-oriented renovators have a significantly higher overall energy quality.

Result 2: Future-oriented renovators have a significantly higher estimated energy quality.

In regression models (3), (4) and (5), in which we add controls for the age and size of the house as well as a proxy for homeowners' financial position, we find that also pro-environmental preferences also relate positively to the overall quality of their house.

Result 3: Pro-environmental homeowners have a significantly higher estimated energy quality.

We now turn to social preferences. Recall, we use two different measures for social preferences: In the Generosity Game, giving money to the other player is costless; in the Dictator Game, giving to the other player is costly. We find that the share offered to the other player in a Dictator Game tends to relate positively to the energy quality of the house. The share offered in the Generosity Game instead tends to relate negatively to the energy quality. Focusing on Model (4), which includes our additional controls, only the Fairness coefficient is significant. However, taking the potential selection into account, both coefficients are insignificant for the renovation decision but 
significant for the estimated efficiency of renovated houses (see Model (5)). We summarize this finding in Result 4:

Result 4: Renovators who are generous with their own money (Dictator Game) have a higher estimated energy quality. Renovators who are generous when it is costless (Generosity Game) have houses with lower estimated energy quality.

Table 4: Estimated overall energy quality of houses and Heckman selection

\begin{tabular}{|c|c|c|c|c|c|c|}
\hline & $(1)$ & $(2)$ & (3) & (4) & \multicolumn{2}{|c|}{$(5)$} \\
\hline & Full sample & $\begin{array}{c}\text { Renovated } \\
\text { houses }\end{array}$ & Full sample & $\begin{array}{c}\text { Renovated } \\
\text { houses }\end{array}$ & \multicolumn{2}{|c|}{ Heckman selection model } \\
\hline Dependent variable & \multicolumn{4}{|c|}{ Estimated energy quality } & $\begin{array}{l}\text { Selection: } \\
\text { Renovated } \\
(\text { Yes/No) }\end{array}$ & $\begin{array}{c}\text { Estimated } \\
\text { energy quality }\end{array}$ \\
\hline Risk-taking (from 1 to 5 ) & $\begin{array}{c}\mathbf{0 . 0 7 3} * * * \\
(0.021)\end{array}$ & $\begin{array}{c}0.010 \\
(0.044)\end{array}$ & $\begin{array}{c}\mathbf{0 . 0 7 6}^{*} * * \\
(0.021)\end{array}$ & $\begin{array}{c}0.015 \\
(0.035)\end{array}$ & $\begin{array}{c}\mathbf{0 . 1 4 7 * *} \\
(0.067)\end{array}$ & $\begin{array}{c}0.042 \\
(0.042)\end{array}$ \\
\hline $\begin{array}{l}\text { Discount factor } \\
\text { (from } 0.747 \text { to } 1 \text { ) }\end{array}$ & $\begin{array}{c}0.208 \\
(0.238)\end{array}$ & $\begin{array}{c}\mathbf{1 . 1 3 6}^{* * * *} \\
(0.395)\end{array}$ & $\begin{array}{c}0.304 \\
(0.280)\end{array}$ & $\begin{array}{c}1.268 * * \\
(0.503)\end{array}$ & $\begin{array}{c}0.020 \\
(1.167)\end{array}$ & $\begin{array}{c}\text { 1.223*** } \\
(0.414)\end{array}$ \\
\hline $\begin{array}{l}\text { Pro-environmental } \\
\text { (from } 0 \text { to } 9 \text { ) }\end{array}$ & $\begin{array}{c}0.004 \\
(0.006)\end{array}$ & $\begin{array}{c}0.001 \\
(0.006)\end{array}$ & $\begin{array}{c}\mathbf{0 . 0 1 5} * * \\
(0.006)\end{array}$ & $\begin{array}{c}\mathbf{0 . 0 2 1} * * \\
(0.008)\end{array}$ & $\begin{array}{c}0.004 \\
(0.028)\end{array}$ & $\begin{array}{c}\mathbf{0 . 0 2 2} * * \\
(0.009)\end{array}$ \\
\hline $\begin{array}{l}\text { Generosity } \\
\text { (from } 0.1 \text { to } 0.9 \text { ) }\end{array}$ & $\begin{array}{c}\mathbf{- 0 . 1 9 3} * * \\
(0.078)\end{array}$ & $\begin{array}{c}-\mathbf{0 . 3 5 0} * * * \\
(0.106)\end{array}$ & $\begin{array}{l}-0.082 \\
(0.079)\end{array}$ & $\begin{array}{l}-0.215 \\
(0.138)\end{array}$ & $\begin{array}{l}-0.395 \\
(0.304)\end{array}$ & $\begin{array}{c}\mathbf{- 0 . 2 9 7 * *} \\
(0.127)\end{array}$ \\
\hline $\begin{array}{l}\text { Fairness } \\
\text { (from } 0.1 \text { to } 0.9 \text { ) }\end{array}$ & $\begin{array}{c}\mathbf{0 . 2 4 1} * * \\
(0.094)\end{array}$ & $\begin{array}{c}\mathbf{0 . 3 3 7 * * * *} \\
(0.100)\end{array}$ & $\begin{array}{c}0.109 \\
(0.096)\end{array}$ & $\begin{array}{c}\mathbf{0 . 2 3 6} * * \\
(0.088)\end{array}$ & $\begin{array}{l}-0.192 \\
(0.299)\end{array}$ & $\begin{array}{c}\mathbf{0 . 2 5 5 * * *} \\
(0.088)\end{array}$ \\
\hline 14-17 year old house & & & $\begin{array}{l}-0.006 \\
(0.043)\end{array}$ & $\begin{array}{c}0.156 \\
(0.115)\end{array}$ & $\begin{array}{c}0.058 \\
(0.182)\end{array}$ & $\begin{array}{c}0.166 \\
(0.130)\end{array}$ \\
\hline 18-32 year old house & & & $\begin{array}{c}\mathbf{- 0 . 0 8 5} * * * \\
(0.028)\end{array}$ & $\begin{array}{c}0.085 \\
(0.075)\end{array}$ & $\begin{array}{c}\mathbf{1 . 0 1 8}^{* * * *} \\
(0.188)\end{array}$ & $\begin{array}{c}\text { 0.316**** } \\
(0.097)\end{array}$ \\
\hline House older than 32 years & & & $\begin{array}{c}\mathbf{- 0 . 3 8 1} * * * \\
(0.032)\end{array}$ & $\begin{array}{c}-\mathbf{- 0 . 2 3 9} * * * \\
(0.083)\end{array}$ & $\begin{array}{c}\mathbf{2 . 0 7 9} * * * \\
(0.131)\end{array}$ & $\begin{array}{l}\mathbf{0 . 1 6 0 *} \\
(0.095)\end{array}$ \\
\hline $\log ($ House size $)$ & & & $\begin{array}{c}\mathbf{0 . 0 9 8} * * \\
(0.044)\end{array}$ & $\begin{array}{c}\mathbf{0 . 2 1 3} * * * \\
(0.027)\end{array}$ & $\begin{array}{c}0.030 \\
(0.211)\end{array}$ & $\begin{array}{c}\mathbf{0 . 2 1 5} * * * \\
(0.034)\end{array}$ \\
\hline $\begin{array}{l}\text { Good financial position } \\
\text { (from } 1 \text { to } 3 \text { ) }\end{array}$ & & & $\begin{array}{c}0.026 \\
(0.027)\end{array}$ & $\begin{array}{l}\mathbf{0 . 0 7 4} * \\
(0.042)\end{array}$ & $\begin{array}{l}-0.001 \\
(0.289)\end{array}$ & $\begin{array}{c}0.069 \\
(0.084)\end{array}$ \\
\hline Constant & $\begin{array}{c}2.955 * * * \\
(0.285)\end{array}$ & $\begin{array}{c}2.282 * * * \\
(0.425)\end{array}$ & $\begin{array}{c}2.301 * * * \\
(0.517)\end{array}$ & $\begin{array}{c}0.747 \\
(0.524)\end{array}$ & $\begin{array}{l}-1.137 \\
(1.238)\end{array}$ & $\begin{array}{c}0.285 \\
(0.653)\end{array}$ \\
\hline Observations & 342 & 145 & 342 & 145 & 342 & 342 \\
\hline \# of clusters & 167 & 41 & 167 & 41 & 167 & 167 \\
\hline $\begin{array}{l}\text { R-squared / } \lambda \\
\text { Robust Std. Error of } \lambda\end{array}$ & 0.034 & 0.061 & 0.194 & 0.229 & & \\
\hline
\end{tabular}

Note: Cluster-robust standard errors in parentheses. Model (5): $\lambda=\rho \sigma$, where $\rho=$ correlation of the error terms of the two regressions, $\sigma=$ the standard error of the residual in the efficiency equation.

\subsubsection{Energy consumption and preferences}

We now turn to the question of whether our preference measures significantly relate to energy consumption behavior. To be able to do so, we elicited for the subsample of homeowners in the 
second wave the annual heating and energy costs. In Table 5 we regress total heating and energy costs on our preference measures. Model (1) includes only the preference measures as dependent variables. As hypothesized, pro-environmental preferences relate negatively to the annual heating and energy costs but prosocial preferences do not significantly relate to energy and heating costs. In Model (2) we additionally add a set of control variables that are likely to influence heating and energy costs (the age and size of the house, the number of persons in the household, the financial position of the owner). To control for the energy efficiency of the house, we also include the estimated energy quality of the house as an explanatory variable in Model (2). Even if we do so, pro-environmental homeowners have lower energy and heating costs.

Table 5: Annual heating and energy costs

\begin{tabular}{|c|c|c|}
\hline & $(1)$ & $(2)$ \\
\hline & \multicolumn{2}{|c|}{ Annual Heating and Energy Costs } \\
\hline \multirow[t]{2}{*}{ Risk-taking (from 1 to 5) } & 172.470 & 199.270 \\
\hline & (137.609) & $(133.793)$ \\
\hline \multirow[t]{2}{*}{ Discount factor (from 0.747 to 1 ) } & $-2,052.465 *$ & $-2,372.208 * *$ \\
\hline & $(1,147.551)$ & $(1,055.977)$ \\
\hline \multirow[t]{2}{*}{ Pro-environmental (from 0 to 9) } & $-148.452 * * *$ & $-121.052 * * *$ \\
\hline & $(44.543)$ & $(45.192)$ \\
\hline \multirow[t]{2}{*}{ Generosity (from 0.1 to 0.9 ) } & 463.180 & 280.034 \\
\hline & $(474.421)$ & $(432.527)$ \\
\hline \multirow[t]{2}{*}{ Fairness (from 0.1 to 0.9 ) } & -524.665 & -276.523 \\
\hline & $(701.561)$ & $(564.176)$ \\
\hline \multirow{2}{*}{ 14-17 year old house } & & -32.080 \\
\hline & & (194.819) \\
\hline \multirow{2}{*}{ 18-32 year old house } & & -367.756 \\
\hline & & $(290.665)$ \\
\hline \multirow[t]{2}{*}{ House older than 32 years } & & 198.413 \\
\hline & & $(328.376)$ \\
\hline \multirow[t]{2}{*}{ Log(House size $)$} & & $833.437 *$ \\
\hline & & $(483.867)$ \\
\hline \multirow[t]{2}{*}{ Number of household members } & & 254.913 \\
\hline & & $(157.318)$ \\
\hline \multirow[t]{2}{*}{ Number of household members ${ }^{2}$} & & -25.905 \\
\hline & & $(17.145)$ \\
\hline \multirow[t]{2}{*}{ Good financial position (from 1 to 3 ) } & & -132.494 \\
\hline & & $(220.215)$ \\
\hline \multirow[t]{2}{*}{ Estimated energy quality (from 2.535 to 4.045 ) } & & -325.735 \\
\hline & & $(306.348)$ \\
\hline \multirow[t]{2}{*}{ Constant } & $5,002.098 * * *$ & $1,660.419$ \\
\hline & $(1,001.763)$ & $(2,084.716)$ \\
\hline Observations & 170 & 170 \\
\hline \# of clusters & 154 & 154 \\
\hline R-squared & 0.104 & 0.218 \\
\hline
\end{tabular}


Although our theoretical framework does not predict differences in energy consumption for more future oriented homeowners, the regressions in Table 5 indicate that homeowners with high discount factors have lower energy and heating costs even when we control for the energy efficiency of the house. We conclude with Result 5:

Result 5: Pro-environmental and future oriented homeowners have lower heating and energy costs (controlling for the estimated energy quality of the house).

\section{Conclusions and policy implications}

The building sector is one of the most energy consuming sectors but also offers large possibilities for greenhouse gas abatement. A reduction in households' energy consumption can help to reduce greenhouse emissions and is crucial for sustainable development of the housing market. For a better understanding of households' behavior in terms of reduction of energy expenses in their homes, we analyze which preferences of households drive their investments in energy saving measures for their houses. First, homeowners' willingness to take risks relates positively to the likelihood of having renovated the house. Second, renovators who are pro-environmental or value the far future more than the near future live in houses with higher energy efficiency. Third, proenvironmental and future oriented homeowners have lower heating and energy costs (controlling for the quality of their home).

Our results provide a better understanding of households' investments into a public good (the environment) in a complex context with uncertain and future returns. We observe that private returns from the public good are the first dimension households take into account. The fact that returns are uncertain and occur in the future drives households' decisions whether to renovate and to what extent. Policies aimed at enhancing energy efficient building renovation (or construction) may therefore focus on providing financing schemes that reduce the risk of the renovation. However, such schemes may also be provided by the market. For instance, (risk neutral) energy 
companies may engage in supporting energy efficient renovations by sharing the costs, risks as well as the benefits of future savings. By this means, contracting on renovations may help to realize investments which are profitable but too risky to be undertaken by homeowners who are not willing to take risks themselves. Similar to zero-percent financing and leasing models that help customers to buy energy efficient refrigerators or washing machines, such a policy could make the housing sector more sustainable. Similarly, policies may aim at providing "early benefits" for homeowners who decide to renovate in order to make less future oriented homeowners more willing to renovate in a more energy efficient way.

Apart from potential policy implications our study also provides insights on the external validity of preference measures developed and commonly used in lab experiments. We find that several of our incentivized preference measures relate in the expected way to renovation and energy consumption behavior. Thus, reluctance in investments should not only be understood as an individual energy efficiency gap but also as a reflection of homeowners' risk, time environmental and social preferences. 


\section{References}

Achtnicht, M., 2011. Do environmental benefits matter? Evidence from a choice experiment among house owners in Germany. Ecological Economics 70, 2191-2200.

Achtnicht, M., Madlener, R., 2014. Factors influencing German house owners' preferences on energy retrofits. Energy Policy 68, 254-263.

Alberini, A., Banfi, S., Filippini, M., Jakob, M., Knellwolf-Pióro, D., Ramseier, C., 2011. Mikroökonomische Analyse für Renovationsverhaltens von Einfamilienhaus-Besitzern, Schlussbericht Bundesamt für Energie (BFE).

Alberini, A., Banfi, S., Ramseier, C., 2013. Energy efficiency investments in the home: Swiss homeowners and expectations about future energy prices. Energy Journal 34, 49-86.

Alberini, A., Filippini, M., 2011. Response of residential electricity demand to price: The effect of measurement error. Energy Economics 33, 889-895.

Allcott, H., 2011. Social norms and energy conservation. Journal of Public Economics 95, 10821095.

Allcott, H., Greenstone, M., 2012. Is there an energy efficiency gap? The Journal of Economic Perspectives 26, 3-28.

Allcott, H., Mullainathan, S., Taubinsky, D., 2014. Energy policy with externalities and internalities. Journal of Public Economics 112, 72-88.

Andreoni, J., Sprenger, C., 2012. Risk preferences are not time preferences. The American Economic Review 102, 3357-3376.

Baddeley, M., 2011. Energy, the environment and behaviour change: A survey of insights from behavioural economics. Cambridge Working Papers in Economics, No. 1162.

Balaras, C.A., Gaglia, A.G., Georgopoulou, E., Mirasgedis, S., Sarafidis, Y., Lalas, D.P., 2007. European residential buildings and empirical assessment of the Hellenic building stock, energy consumption, emissions and potential energy savings. Building and Environment 42, 1298-1314.

Banfi, S., Farsi, M., Filippini, M., Jakob, M., 2008. Willingness to pay for energy-saving measures in residential buildings. Energy Economics 30, 503-516.

Banfi, S., Filippini, M., Ramseier, C., 2010. Erneuerung von Einfamilienhäusern. Eine mikroökonomische Analyse für ausgewählte Schweizer Kantone. Tech. rep., Bundesamt für Energie (BFE).

Bardhan, A., Jaffee, D., Kroll, C., Wallace, N., 2014. Energy efficiency retrofits for US housing: Removing the bottlenecks. Regional Science and Urban Economics 47, 45-60.

Bento, A.M., Li, S., Roth, K., 2012. Is there an energy paradox in fuel economy? A note on the role of consumer heterogeneity and sorting bias. Economics Letters 115, 44-48.

Benz, M., Meier, S., 2008. Do people behave in experiments as in the field? - Evidence from donations. Experimental Economics 11, 268-281.

Boersch-Supan, A.H., Essig, L., 2005. Household saving in Germany: Results of the first SAVE study, Analyses in the Economics of Aging. University of Chicago Press, 317-356.

Brounen, D., Kok, N., Quigley, J.M., 2012. Residential energy use and conservation: Economics and demographics. European Economic Review 56, 931-945.

Cameron, T.A., 1985. A nested logit model of energy conservation activity by owners of existing single family dwellings. The Review of Economics and Statistics 67, 205-211.

Chabris, C.F., Laibson, D., Morris, C.L., Schuldt, J.P., Taubinsky, D., 2008. Individual laboratorymeasured discount rates predict field behavior. Journal of Risk and Uncertainty 37, 237-269. 
Chong, H., 2012. Building vintage and electricity use: Old homes use less electricity in hot weather. European Economic Review 56, 906-930.

Clinch, J.P., Healy, J.D., 2000. Domestic energy efficiency in Ireland: correcting market failure. Energy Policy 28, 1-8.

Dastrup, S.R., Graff Zivin, J., Costa, D.L., Kahn, M.E., 2012. Understanding the Solar Home price premium: Electricity generation and "Green" social status. European Economic Review 56, 961973.

De Oliveira, A., Croson, R.T., Eckel, C.C., 2012. The stability of social preferences in a lowincome neighborhood. Southern Economic Journal 79, 15-45.

Dohmen, T., Falk, A., Huffman, D., Sunde, U., Schupp, J., Wagner, G.G., 2011. Individual risk attitudes: Measurement, determinants, and behavioral consequences Journal of the European Economic Association 9, 522-550.

Dunlap, R.E., Van Liere, K.D., 1978. The new environmental paradigm. A proposed measuring instrument and preliminary results. Journal of Environmental Education 9, 10-19.

Eichholtz, P., Kok, N., Quigley, J.M., 2010. Doing well by doing good? Green office buildings. The American Economic Review 100, 2492-2509.

Eichholtz, P., Quigley, J.M., 2012. Green building finance and investments: Practice, policy and research. European Economic Review 56, 903-904.

Engel, C., 2011. Dictator games: A meta study. Experimental Economics 14, 583-610.

Enkvist, P., Nauclér, T., Rosander, J., 2007. A cost curve for greenhouse gas reduction. McKinsey Quarterly 1, 35-45.

Epper, T., Fehr-Duda, H., Schubert, R., 2011. Energy-using durables: the role of time discounting in investment decisions. Institute for Environmental Decision (IED) Working Paper No. 6.

Evans, J., Filippini, M., Hunt, L.C., 2011. Measuring energy efficiency and its contribution towards meeting CO2 targets: estimates for 29 OECD countries. Surrey Energy Economics Centre (SEEC), Discussion Paper. .

Farsi, M., 2010. Risk aversion and willingness to pay for energy efficient systems in rental apartments. Energy Policy 38, 3078-3088.

Frederick, S., Loewenstein, G., O'Donoghue, T., 2002. Time discounting and time preference: A critical review. Journal of Economic Literature 40, 351-401.

Gillingham, K., Palmer, K., 2014. Bridging the energy efficiency gap: Policy insights from economic theory and empirical evidence. Review of Environmental Economics and Policy 9.

Golove, W.H., Eto, J.H., 1996. Market barriers to energy efficiency: A critical reappraisal of the rationale for public policies to promote energy efficiency. LBL-38059. Berkeley, CA: Lawrence Berkeley National Laboratory.

Gowdy, J.M., 2008. Behavioral economics and climate change policy. Journal of Economic Behavior \& Organization 68, 632-644.

Hassett, K.A., Metcalf, G.E., 1993. Energy conservation investment: Do consumers discount the future correctly? Energy Policy 21, 710-716.

Hausman, J.A., 1979. Individual discount rates and the purchase and utilization of energy-using durables. The Bell Journal of Economics 10, 33-54.

Holt, C.A., Laury, S.K., 2002. Risk aversion and incentive effects. American Economic Review 92, 1644-1655.

Intergovernmental Panel on Climate Change, 2007. Climate Change 2007: The Physical Science Basis. Cambridge University Press, Cambridge, UK.

Jaffe, A.B., Stavins, R.N., 1994. The energy-efficiency gap What does it mean? Energy policy 22, 804-810. 
Jakob, M., 2007. Essays in economics of energy efficiency in residential buildings: An empirical analysis. ETH.

Jakob, M., Madlener, R., 2004. Riding down the experience curve for energy-efficient building envelopes: the Swiss case for 1970-2020. International Journal of Energy Technology and Policy 2, 153-178.

Jochem, E., Jakob, M., 2004. Energieperspektiven und CO2-Reduktionspotenziale in der Schweiz. bis 2010: Energieeffizienz sowie Substitution durch Erdgas und erneuerbare Energien. vdf Hochschulverlag, Zürich.

Jochem, E., Jakob, M., Glatthard, T., Sidler, C., 2003. Kosten und Nutzen: Wärmeschutz bei Wohnbauten. Vertrieb: BBL, Vertrieb Publikationen.

Kwak, S.-Y., Yoo, S.-H., Kwak, S.-J., 2010. Valuing energy-saving measures in residential buildings: A choice experiment study. Energy Policy 38, 673-677.

Levine, M.D., Koomey, J.G., McMahon, J.E., Sanstad, A.H., Hirst, E., 1995. Energy efficiency policy and market failures. Annual Review of Energy and the Environment 20, 535-555.

Levinson, A., Niemann, S., 2004. Energy use by apartment tenants when landlords pay for utilities. Resource and Energy Economics 26, 51-75.

McKinsey\&Co, 2009. Unlocking Energy Efficiency in the U.S. Economy, http://www.mckinsey.com/clientservice/electricpowernaturalgas/downloads/US_energy_efficiency _full_report.pdfhttp://www.mckinsey.com/clientservice/electricpowernaturalgas/downloads/US_e nergy_efficiency_full_report.pdf (accessed: 15/04/30).

Metcalf, G.E., Hassett, K.A., 1999. Measuring the energy savings from home improvement investments: evidence from monthly billing data. Review of Economics and Statistics 81, 516-528.

Nair, G., Gustavsson, L., Mahapatra, K., 2010. Factors influencing energy efficiency investments in existing Swedish residential buildings. Energy Policy 38, 2956-2963.

Newell, R.G., Siikamaki, J.V., 2015. Individual Time Preferences and Energy Efficiency. NBER Working Paper No. 20969.

Poortinga, W., Steg, L., Vlek, C., Wiersma, G., 2003. Household preferences for energy-saving measures: A conjoint analysis. Journal of Economic Psychology 24, 49-64.

Qiu, Y., Colson, G., Grebitus, C., 2014. Risk preferences and purchase of energy-efficient technologies in the residential sector. Ecological Economics 107, 216-229.

RICS, 2005. Green value: green buildings, growing assets, London and Vancouver: Royal Institution of Chartered Surveyors.

Sadler, M., 2003. Home energy preferences \& policy: Applying stated choice modeling to a hybrid energy economy model. Report to Natural Resources Canada, Simon Fraser University.

Scarpa, R., Willis, K., 2010. Willingness-to-pay for renewable energy: Primary and discretionary choice of British households' for micro-generation technologies. Energy Economics 32, 129-136.

Smith, V.K., Moore, E.M., 2010. Behavioral economics and benefit cost analysis. Environmental and Resource Economics 46, 217-234.

Stern, N., 2008. The economics of climate change. The American Economic Review 98, 1-37.

Train, K., 1985. Discount rates in consumers' energy-related decisions: A review of the literature. Energy 10, 1243-1253. 


\section{Online Appendix: Survey and experimental material}

Below we provide the material used in the second wave (translated from German).

\section{i. Letter (page 1)}

John Doe

123 Main Street

87654 Swisstown,

Switzerland

October 25, 2011

Study on Swiss home owners' investment behavior

Dear Mr. Doe,

The Thurgau Institute of Economics (TWI) is an institute associated with the University of Constance and is financed by the Thurgau Foundation for Science and Research. Supported by the Swiss Federal Office of Energy (SFOE), we are currently carrying out a study on investment decisions of home owners. The objective of the study is to develop meaningful assistance measures for investments.

You have been randomly selected out of a group of Swiss building owners as a possible participant of the study. We would be very pleased if you supported our research project. The study uses new research methods from behavioral economics. That is, apart from answering a survey questions, you will also make decisions about monetary amounts. As usual in behavioral economics, you will receive real monetary amounts. For your participation, you will be receive between 15.- and 118.- Sfr. The completion of the necessary documents of the study takes about 10 to 20 minutes.

The supplementary sheet "information for participants" provides you with information on the most important questions. Further information is provided online at www.investitionsstudie.twi-kreuzlingen.ch. If you have any further questions, please do not hesitate to contact us either by email: investitionsstudie@twi-kreuzlingen.ch or telephone: 07167705 18. Your contact person for this study is Simeon Schudy.

We are looking forward to your response.

Kind regards,

Prof. Dr. Urs Fischbacher

Director of the Thurgau Institute of Economics (TWI)

Attachments: Information for participants, questionnaire, return envelope, supplementary sheet for payment. 


\section{ii. Letter (page 2)}

\section{Information for participants}

\section{Data Protection and Data Use}

The Thurgau Institute of Economics (TWI) guarantees to analyze only anonymized data. The data will solely be used for scientific purposes. Commercial use of the data is prohibited. Individual data will not be provided to third parties.

\section{Who should fill out the questionnaire?}

The questionnaire shall be filled out by the person in the household, who is primarily involved in making the household's investment decisions.

\section{Why should I participate?}

If you participate, you contribute to fundamental research on investment decisions and help to develop new assistance measures for investments. Additionally, you receive a financial compensation for your participation.

\section{How do I participate and how do I receive the financial compensation?}

We ask you to put the completed material in the provided envelope and mail it to the Thurgau Institute of Economics. We will send you the Fr. 10.- for your participation as well as the additional payment, which results from your decisions, via mail. The budget of this study is large enough to monetarily compensate all participants. More information on the selection of the relevant payments for your decisions is provided at: www.investitionsstudie.twikreuzlingen.ch

\section{Explanation of the approach of behavioral economics}

Behavioral Economics is a sub-discipline in economics that studies human behavior in economically relevant decision situations. Behavioral economists use monetary payments to create decision environments that reproduce economically relevant decision environments. Study participants make decisions that affect their payments. Results from such studies provide insights for socially relevant problems. For example, behavioral economics studies questions such as:

Why do we observe speculative bubbles on stock markets?

Which incentives do bonus-contracts create?

How can we manage common property?

Although Behavioral Economics is a young research discipline, in 2002 Vernon Smith received the Sveriges Riksbank Prize in Economic Sciences in Memory of Alfred Nobel for the use of these research methods. In 2009, Elinor Ostrom, who also applied the methods from Behavioral Economics, received this Economics Nobel prize as the first woman. Similarly, we use methods from behavioral economics this study. You will make decisions about monetary payments and you will receive monetary amounts based on your (or others) decisions.

You have more questions? - Contact us!

Email: investitionsstudie@twi-kreuzlingen.ch

Phone: 0716770518

Internet: www.investitionsstudie.twi-kreuzlingen.ch

You would like to know more about our research?

Visit our website at the University of Konstanz:

http://expecon.wiwi.uni-konstanz.de/ 
iii. Letter (page 3)

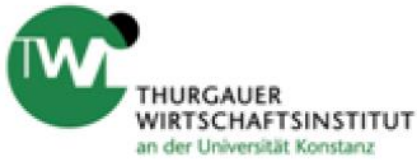

\section{Supplementary sheet for payment (please enclose in return envelope)}

Dear Mr Doe,

Please return this sheet together with the completed questionnaire. On receipt, we will separate the sheet from the questionnaire. It is only used for the payment of your decisions.

The amount of money, resulting from your decisions, is to be paid to:

John Doe 


\section{iv. Questionnaire and incentivized decision tasks}

THURGAUER

WIRTSCHAFTSINSTITUT

an der Univeritat Konstanz

Investment decisions (building)

Please answer the following questions about your building.

\begin{tabular}{lll}
\hline What kind of building do you own? & $\square$ single family house & $\square$ apartment building \\
Do you live in the building? & $\square$ yes & $\square$ no
\end{tabular}

How large is the living space of the building (approx.)?

How many sources of light exist in the building (approx.)?

How many light sources use energy efficient bulbs?

How many people live in the building (approx.)?

How large are your annual heating costs (approx.)?

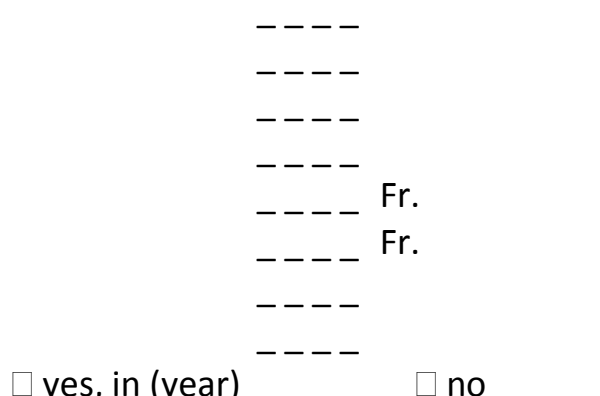

How large are your annual energy costs (approx.)?

When was the building build (year)?

When was the building renovated for the last time (year)?

Is a renovation planned in the future?

What is the current state of the ...

$\begin{aligned} \text { Windows: } \quad & \square \text { very good insulation (triple insulated) } \\ & \square \text { normal insulation (coated glass, complete rubber coating) } \\ & \square \text { medium-old insulation (uncoated glass, no rubber insulation) } \\ & \square \text { old insulation (single glass pane, no coating) }\end{aligned}$

Facade: $\quad \square$ improved insulation

$\square$ standard insulation

$\square$ no insulation but recently painted

$\square$ Old, no insulation, not recently painted

Ventilation: $\quad \square$ Controlled ventilation $\quad \square$ no controlled ventilation

Roof: $\quad \square$ very good insulation

$\square$ normal insulation

$\square$ middle-old insulation

$\square$ old insulation
How do you heat the house mainly (check as many as apply)?
$\square$ oil firing $\square$ gas firing $\square$ wood firing $\square$ electric heating $\square$ heat pump
other:
How do you rate the energy efficiency of your house?
$\square$ Very low $\quad \square$ low $\quad \square$ medium $\quad \square$ high $\quad \square$ very high
How do you rate the energy efficiency of buildings in the direct neighborhood?
$\square$ Very low $\quad \square$ low $\quad \square$ medium $\quad \square$ high $\quad \square$ very high
Does your building fulfill a MINERGIE ${ }^{\circledR}$ - Standard? $\quad \square$ yes $\quad \square$ no




\section{Attitudes and Investment behavior}

Are you a person willing to take risks or do you try to avoid risks?

Please rate your willingness to take risks in the following areas.

\begin{tabular}{|c|c|c|c|c|c|}
\hline & $\begin{array}{l}\text { not at all } \\
\text { risk seeking }\end{array}$ & & & & $\begin{array}{l}\text { very } \\
\text { king }\end{array}$ \\
\hline in general & $\square$ & $\square$ & $\square$ & $\square$ & $\square$ \\
\hline in car-driving & $\square$ & $\square$ & $\square$ & $\square$ & $\square$ \\
\hline in financial decisions & $\square$ & $\square$ & $\square$ & $\square$ & $\square$ \\
\hline in leisure and sport & $\square$ & $\square$ & $\square$ & $\square$ & $\square$ \\
\hline in your professional career & $\square$ & $\square$ & $\square$ & $\square$ & $\square$ \\
\hline
\end{tabular}

To what extent do you agree personally with the following statements?

\begin{tabular}{|c|c|c|c|c|c|}
\hline & \multicolumn{3}{|c|}{ No approval } & \multicolumn{2}{|c|}{ full approval } \\
\hline $\begin{array}{l}\text { People in our society should } \\
\text { be dutiful. }\end{array}$ & $\square$ & $\square$ & $\square$ & $\square$ & $\square$ \\
\hline $\begin{array}{l}\text { We are approaching the limit } \\
\text { of people, who can be fed } \\
\text { by the earth. }\end{array}$ & $\square$ & $\square$ & $\square$ & $\square$ & $\square$ \\
\hline $\begin{array}{l}\text { To survive, people have to live } \\
\text { In harmony with nature }\end{array}$ & $\square$ & $\square$ & $\square$ & $\square$ & $\square$ \\
\hline $\begin{array}{l}\text { People in our society should } \\
\text { Accomplish something in their } \\
\text { work. }\end{array}$ & $\square$ & $\square$ & $\square$ & $\square$ & $\square$ \\
\hline $\begin{array}{l}\text { People do not have to adapt } \\
\text { to nature, because they can } \\
\text { re-establish nature to their } \\
\text { own best. }\end{array}$ & $\square$ & $\square$ & $\square$ & $\square$ & $\square$ \\
\hline $\begin{array}{l}\text { People in our society should } \\
\text { help and support each other. }\end{array}$ & $\square$ & $\square$ & $\square$ & $\square$ & $\square$ \\
\hline
\end{tabular}

If you reflect how you (and your partner) managed on with your income in 2010: What describes the situation best?

At the end of the month there was a lot of money left.

At the end of the month there was frequently some money left.

There was only money left, if an additional non-recurring income occurred.

At the end of the month it was often not enough.

At the end of the month the money was never enough.

Which of the following statement fits best your (and your partner's) savings behavior?

$\square \quad$ I/we save a fixed amount regularly, in a savings account, a savings contract, shares or life
insurance.
$\square \quad$ I/we save some money every month, but I/we adjust the amount to the current financial situation.
$\square \quad$ I/we save something, if there is something to save left.
$\square \quad$ I/we do not save, because there is little leeway for saving.
$\square \quad$ I/we do not want to save but instead enjoy our life today.




\section{Decision making situations}

We kindly ask you now to make several decisions about different monetary amounts.

- You will receive a monetary amount for your participation.

- The amount you receive depends on your and other participants' decisions.

- For each participant, exactly one decision will be paid.

- It will be randomly determined which decision will be paid

- The budget is large enough to pay all participants

You will receive a flat payment of Fr. 10.- for participating in this study. On receipt of your completed questionnaire, the payment will be sent to you by mail (within a month). Additionally, you will receive an amount of money from one of the decision making situations ranging from Fr. 5.- to Fr. 108.-.

You find detailed information about the payment procedure on:

www.investitionsstudie.twi-kreuzlingen.ch 
Your decision:

- $\quad$ You decide how much money another randomly chosen participant receives

- $\quad$ If your decision is chosen to be paid, you receive Fr. 25.- and another randomly chosen participant receives the amount you chose (Fr. 5.- to Fr. 45.-)

How do you distribute the money?

\begin{tabular}{|l|c|c|c|c|c|c|c|c|c|}
\hline You Receive & \multicolumn{9}{|c|}{ Fr. 25.- } \\
\hline $\begin{array}{l}\text { Another } \\
\text { participant } \\
\text { receives }\end{array}$ & Fr. 45.- & Fr. 40.- & Fr. 35.- & Fr. 30.- & Fr. 25.- & Fr. 20.- & Fr. 15.- & Fr. 10.- & Fr. 5.- \\
\hline Your decision & $\square$ & $\square$ & $\square$ & $\square$ & $\square$ & $\square$ & $\square$ & $\square$ & $\square$ \\
\hline
\end{tabular}

Please select exactly one amount!

You may also be randomly selected to be paid an amount determined by a randomly chosen participant.

You have selected exactly one amount? Please continue with Decision Situation 2. 


\section{Situation 2}

Your decision

- $\quad$ You will decide on how Fr. 50.- are divided between you and another randomly chosen participant

- $\quad$ This is not the same participant as in Decision Situation 1.

How do you distribute the money?

\begin{tabular}{|l|c|c|c|c|c|c|c|c|c|}
\hline You Receive & Fr. 5.- & Fr. 10.- & Fr. 15.- & Fr. 20.- & Fr. 25.- & Fr. 30.- & Fr. 35.- & Fr. 40.- & Fr. 45.- \\
\hline $\begin{array}{l}\text { Another } \\
\text { participant } \\
\text { receives }\end{array}$ & Fr. 45.- & Fr. 40.- & Fr. 35.- & Fr. 30.- & Fr. 25.- & Fr. 20.- & Fr. 15.- & Fr. 10.- & Fr. 5.- \\
\hline Your decision & $\square$ & $\square$ & $\square$ & $\square$ & $\square$ & $\square$ & $\square$ & $\square$ & $\square$ \\
\hline
\end{tabular}

Please select exactly one amount!

You may also be randomly selected to be paid an amount determined by a randomly chosen participant.

You have selected exactly one amount? Please continue with Decision Situation 3. 


\section{Situation 3}

Your decision:

- $\quad$ Do you want to receive Fr. 80.- in one month (after we receive your questionnaire) or a higher amount B in seven months?

Please make this decision for the twelve amounts in the list below.

- $\quad$ If Decision Situation 3 is selected to be paid, you will receive the money in one month if you chose amount $A$ and in seven months if you chose amount $B$.

Please make your choice - amount A ( $\mathrm{Fr}$. 80.-in one month) or amount B (higher amount in 7 months) - for each decision number in the respective column.

\begin{tabular}{|c|c|c|c|}
\hline Decision number & $\begin{array}{c}\text { Amount A } \\
\text { (in one month) }\end{array}$ & Your choice & $\begin{array}{c}\text { Amount B } \\
\text { (in seven months) }\end{array}$ \\
\hline 1 & \multirow{12}{*}{ Fr. 80.- } & $\square \mathrm{A} \quad \square \mathrm{B}$ & Fr. 80.00 \\
\hline 2 & & $\square \mathrm{A} \quad \square \mathrm{B}$ & Fr. 80.50 \\
\hline 3 & & $\square \mathrm{A} \quad \square \mathrm{B}$ & Fr. 81.00 \\
\hline 4 & & $\square \mathrm{A} \quad \square \mathrm{B}$ & Fr. 82.00 \\
\hline 5 & & $\square \mathrm{A} \quad \square \mathrm{B}$ & Fr. 83.50 \\
\hline 6 & & $\square \mathrm{A} \quad \square \mathrm{B}$ & Fr. 85.50 \\
\hline 7 & & $\square \mathrm{A} \quad \square \mathrm{B}$ & Fr. 88.00 \\
\hline 8 & & $\square \mathrm{A} \quad \square \mathrm{B}$ & Fr. 91.00 \\
\hline 9 & & $\square \mathrm{A} \quad \square \mathrm{B}$ & Fr. 94.50 \\
\hline 10 & & $\square \mathrm{A} \quad \square \mathrm{B}$ & Fr. 98.50 \\
\hline 11 & & $\square \mathrm{A} \quad \square \mathrm{B}$ & Fr. 103.00 \\
\hline 12 & & $\square \mathrm{A} \quad \square \mathrm{B}$ & Fr. 108.00 \\
\hline
\end{tabular}

Please chose in each row either amount A or B

You have ticked an answer in each row? Then continue with the statistical information 


\begin{tabular}{|llll|}
\hline & \multicolumn{3}{c|}{ General Information } \\
Are you? & $\square$ female $\quad \square$ male & \\
How old are you? & -- & & \\
Which is your & $\square$ apprenticeship & $\square$ Matura & $\square$ University degree \\
highest degree of education? & $\square$ other & & \\
Do you vote? & $\square$ regularly & $\square$ sometimes & $\square$ never \\
Do you donate? & $\square$ regularly & $\square$ sometimes & $\square$ never \\
\hline
\end{tabular}

If you donate, to which kind of organizations do you give?

$$
\begin{aligned}
& \square \text { environmental associations } \\
& \square \text { Social organizations } \\
& \square \text { cultural organizations } \\
& \square \text { Education and Science } \\
& \square \text { other: }
\end{aligned}
$$

How much do you donate per year (in Swiss Francs)?

\section{Thank you for participating in our study!}

You can donate a part of your payment for participation (at most $60 \%$ ) to one of the environmental associations listed below.

- We will double your donation.

- $\quad$ If you give more than $40 \%$ of your payment you have the option to have your name published in a list of donors in the daily newspaper Tagesanzeiger.

The amount donated will not be published.

If you want us to publish your name, please fill in your name for publication here:

Which part of your payment do you want to donate?

$\square 0 \% \quad \square 10 \% \quad \square 20 \% \quad \square 30 \% \quad \square 40 \% \quad \square 50 \% \quad \square 0 \%$

To which organization do you want to donate?
$\square \mathrm{WWF}$
$\square$ Greenpeace
$\square$ Stiftung Bergwaldprojekt
Dequiterre (SGU)

Room for your comments

Thurgauer Wirtschaftsinstitut an der Universität Konstanz, Hauptstrasse 90, 8280 Kreuzlingen 2.

Phone 07167705 18, Email: investitionsstudie@twi-kreuzlingen.ch.

Contact person: Simeon Schudy. 